УДК 662.73

\title{
ПРЕВРАЩЕНИЯ ПОЛИСАХАРИДОВ СОЛОМЫ ПШЕНИЦЫ В ДИНАМИЧЕСКИХ УСЛОВИЯХ ПРОЦЕССА СУБКРИТИЧЕСКОГО АВТОГИдРОЛИЗА
}

\author{
(C) С.Н. Евстафьев", Е.В. Чечикова \\ Иркутский государственный технический университет, ул. Лермонтова, 83, \\ 664074 (Россия), e-mail: artelzin@mail.ru
}

Выполнено исследование превращений полисахаридов соломы пшеницы в динамических условиях субкритического автогидролиза при давлении 30 МПа в интервале температур $150-290{ }^{\circ} \mathrm{C}$. Изучены зависимости выхода газообразных, жидких и твердых продуктов от температуры процесса. В интервале $150-200{ }^{\circ} \mathrm{C}$ формирование жидких продуктов осуществляется в основном за счет гидролиза пентозанов и частично - целлюлозы. Основными компонентами жидких продуктов являются олиго- и моносахариды. В составе моносахаридов более 65\% приходится на ксилозу и арабинозу. Повышение температуры в интервале $200-290{ }^{\circ} \mathrm{C}$ сопровождается понижением рН-среды, гидролизом целлюлозы и интенсивным газообразованием. В составе моносахаридов жидких продуктов, выделенных при $270{ }^{\circ} \mathrm{C}$, доминирует глюкоза, а на долю пентоз приходится не более $25 \%$ от суммы моносахаридов. С повышением температуры процесса суммарный выход сахаров проходит через максимум при $200{ }^{\circ} \mathrm{C}$ с последующим снижением с 29,6 до 5,3\% на а.с.м. соломы при $270{ }^{\circ} \mathrm{C}$. Установлено снижение реакционной способности целлюлозы соломы, обработанной при $200{ }^{\circ} \mathrm{C}$, к ферментативному гидролизу.

Ключевые слова: солома пшеницы, субкритический автогидролиз, целлюлоза, пентозаны, сахара.

\section{Введение}

Полисахариды растительного сырья, представленные целлюлозой и гемицеллюлозами, являются самыми распространенными биологическими полиозами. Они содержатся в биомассе растений, морских водорослей, а также в отходах деревообработки и сельского хозяйства. Предполагается, что использование биомассы растительного сырья позволит в будущем частично решить энергетические проблемы, вызванные нехваткой ископаемого топлива.

Целлюлоза может быть легко гидролизована с использованием кислотных катализаторов [1] или ферментов [2] до растворимых олигосахаридов и глюкозы, являющихся ценным сырьем для органического синтеза и ферментации. В чистом виде целлюлоза в растительном сырье практически не встречается. В биомассе растений она с гемицеллюлозами и лигнином за счет многочисленных меж- и внутримолекулярных водородных и ковалентных связей образует прочный лигноцеллюлозный комплекс, устойчивый к действию ферментов. Экспериментально установлено, что разрушить такой комплекс можно в кислой или щелочной среде [3], что мало пригодно при промышленном использовании как с экологической, так и экономической точек зрения. Одним из самых эффективных на сегодняшний день способов обработки лигно-

Евстафьев Сергей Николаевич - директор института пищевой инженерии и биотехнологии, заведующий кафедрой органической химии и пищевой технологии им. профессора В.В. Тутуриной, доктор химических наук, професcop, e-mail: esn@istu.edu

Чечикова Елена Викторовна - аспирант кафедры органической химии и пищевой технологии им. профессора В.В. Тутуриной, e-mail: artelzin@mail.ru целлюлозы является гидролиз разбавленными растворами кислот (серная, соляная, фосфорная, трифторуксусная или органические кислоты). К недостаткам этого способа можно отнести разложение в условиях обработки (120-200 $\left.{ }^{\circ} \mathrm{C}\right)$ полученных сахаров с образованием ингибиторов процессов ферментолиза и ферментации (фурфурол,

\footnotetext{
* Автор, с которым следует вести переписку.
} 
оксиметилфурфурол и др.), а также использование химических реактивов, коррозию оборудования и необходимость утилизации отходов $[4,5]$.

В последнее время усилия исследователей направлены на разработку экологически безопасных технологий переработки лигноцеллюлозного сырья с использованием нетоксичных растворителей. Одним из таких растворителей является вода, обладающая в суб- и сверхкритических условиях уникальными свойствами [6]. Прежде всего это связано с легкостью варьирования диэлектрической постоянной воды и концентрации ионов водорода при изменении температуры процесса [7], что позволяет использовать ее одновременно как для извлечения органических соединений вместо токсичных растворителей, так и в качестве кислотного катализатора для гидролиза компонентов биомассы лигноцеллюлозы.

Суб- и сверхкритическая вода использовалась для обработки разнообразного лигницеллюлозного сырья [8-10]. Изучение влияния температуры в интервале $100-360{ }^{\circ} \mathrm{C}$ и продолжительности (до 30 мин) на выход и состав продуктов автогидролиза рисовых отрубей приведено в работе [11]. Показано, что преобразования биомассы отрубей в газы и жидкие продукты при температурах до $140{ }^{\circ} \mathrm{C}$ незначительны, а при последующем повышении температуры выход продуктов увеличивается, достигая $92 \%$ при $360{ }^{\circ} \mathrm{C}$. Максимальный выход сахаров (около $10 \%$ на а.с.м.) был получен при $190{ }^{\circ} \mathrm{C}$ в течение 10 мин. При последующем повышении температуры он снижался. Отмечено интенсивное обуглероживание и снижение содержания серы в нерастворимой части отрубей при температурах выше $220{ }^{\circ} \mathrm{C}[6]$.

В работе [12] показано, что процесс автогидролиза соломы ржи может быть с успехом использован для отделения гемицеллюлоз. При температурах выше $200{ }^{\circ} \mathrm{C}$ ксилоза и арабиноза, представляющие более $96 \%$ исходной гемицеллюлозы соломы, практически полностью переходят в жидкие продукты. Гидролиз целлюлозы наблюдается при температурах выше $250^{\circ} \mathrm{C}$, при этом выделяющаяся глюкоза интенсивно превращается в 5-оксиметилфурфурол.

Гидротермальную обработку соломы злаковых культур, в том числе пшеницы [13], проводят обычно в интервале температур $170-230{ }^{\circ} \mathrm{C}$ и давлении свыше 5 МПа. В этих условиях достигается значительный гидролиз гемицеллюлоз до олигасахаридов и повышение выхода сахаров при ферментолизе обработанной соломы.

Большая часть известных в литературе исследований субкритического автогидролиза сельскохозяйственных отходов была выполнена в статических условиях в реакторах пакетного типа [10]. С учетом относительно жестких условий процесса и низкой термостойкости углеводов для получения их высокого выхода целесообразно снижение продолжительности нахождения продуктов автогидролиза в реакторе, что может быть реализовано при проведении процесса в динамических условиях. Кроме того, использованное в экспериментах оборудование не позволило авторам определить выход газов, а также контролировать давление обработки. Давление чаще всего определяли расчетным путем с учетом загрузки реактора и температуры процесса. Все это существенно затрудняет сравнительный анализ полученных результатов. Тем не менее на основании имеющихся данных можно утверждать, что процесс автогидролиза имеет перспективы коммерческого использования для переработки сельскохозяйственных отходов.

Цель работы - выявление влияния температуры на выход и состав продуктов гидролиза полисахаридов соломы пшеницы в динамических условиях процесса субкритического автогидролиза.

\section{Экспериментальная часть}

Работа выполнена с образцами соломы пшеницы крупностью 1-5 мм, предварительно высушенной в сушильном шкафу при температуре $60^{\circ} \mathrm{C}$. Компонентный состав соломы в процентах на а. с. м. соломы: целлюлоза - 38,2; лигнин - 24,4; пентозаны - 21,1.

Автогидролиз проводили в динамическом режиме на лабораторной экстракционной установке [14] при температурах 150, 200, 220, 240, 270 и $290{ }^{\circ} \mathrm{C}$. Продолжительность каждого эксперимента 60 мин, давление 30 МПа.

Солому массой 2-3 г помещали в металлический сетчатый контейнер. Плотность навески составляла $0,1-0,15$ г см $^{3}$. Контейнер с образцом загружали в предварительно нагретый до рабочей температуры экстрактор объемом $250 \mathrm{~cm}^{3}$ и производили герметизацию установки. Дистиллированную воду в экстрактор подавали непрерывно насосом высокого давления. После создания рабочего давления (в течение 8-10 мин) фиксировали время начала эксперимента. 
В результате эксперимента получали газообразные, жидкие и твердые продукты. Под жидкими продуктами понимали растворимую в условиях эксперимента в субкритической воде часть биомассы соломы, а под твердыми - нерастворимую ее часть.

Газы и водный раствор жидких продуктов после экстрактора пропускали через охлаждаемый водой холодильник. Объем газов не фиксировали, а раствор собирали в отдельные пятиминутные фракции объемом 80-100 см ${ }^{3}$ каждая. После окончания эксперимента сбрасывали давление до атмосферного, вынимали контейнер из экстрактора, выгружали из него твердые продукты автогидролиза, сушили их до постоянной массы в вакуумном сушильном шкафу и взвешивали.

Из фракций после отделения нерастворимых при комнатой температуре соединений (НС) центрифугированием на напольной высокоскоростной центрифуге Thermo SCIENTIFIC отгоняли воду в вакууме. Полученные экстракты фракционировали последовательной обработкой гексаном, этанолом и водой по схеме, приведенной на рисунке 1.

Экстракцию проводили при температуре кипения растворителей в течение 1 ч. Для удаления растворителей из полученных экстрактов использовали лиофильную сушку на приборе VaCo 2.

Компонентный состав исходной соломы и твердых продуктов определяли по стандартным методикам [15], элементный анализ их выполнен на анализаторе VarioMicro CUBE.

Количественный состав моносахаридов фракций ЭНП и НВР после их гидролиза трифторуксусной кислотой [16] и силилирования [17] определяли методом ГХ-МС на хроматографе 7820 А с селективным масс-спектрометрическим детектором НР 5975 фирмы «Agilent Technologies». Энергия ионизации - 70 эВ. Температура сепаратора $-280{ }^{\circ} \mathrm{C}$, ионного источника $-230{ }^{\circ} \mathrm{C}$. Кварцевая колонка $30000 \times 0,25$ мм со стационарной фазой (95\% диметил-5\% дифенилполисилоксан). Условия анализа: 3 мин изотермы при $125{ }^{\circ} \mathrm{C}$ с последующим подъемом температуры до $250{ }^{\circ} \mathrm{C}$ со скоростью 6 град/ мин и выдержкой в течение 10 мин при $250{ }^{\circ} \mathrm{C}$. В качестве внутреннего стандарта использовали ксилит. Идентификацию компонентов осуществляли с использованием библиотеки масс-спектров «NIST11».

Глубину протекания процесса автогидролиза контролировали по степени конверсии соломы, гидролиза целлюлозы и делигнификации соломы.

Степень конверсии (СК) соломы, представляющей собой суммарный выход газов и жидких продуктов, вычисляли по формуле

$$
\mathrm{CK}=\left(\mathrm{m}_{1}-\mathrm{m}_{2}\right) \cdot 100 / \mathrm{m}_{1} \text {, в \% на а.с.м. исходной соломы, }
$$

где $\mathrm{m}_{1}$ - масса навески соломы, г; $\mathrm{m}_{2}$ - масса твердого продукта, г.

Степень гидролиза целлюлозы определяли как отношение массы целлюлозы, удаленной при обработке, к массе целлюлозы в исходной навеске соломы, выраженное в процентах.

Степень делигнификации определяли как отношение массы лигнина, удаленного при обработке, к массе лигнина в исходной навеске соломы, выраженное в процентах.

Выход газов (в \% на а.с.м исходной соломы) вычисляли по разности степени конверсии и выхода жидких продуктов (в \% на а.с.м. исходной соломы).

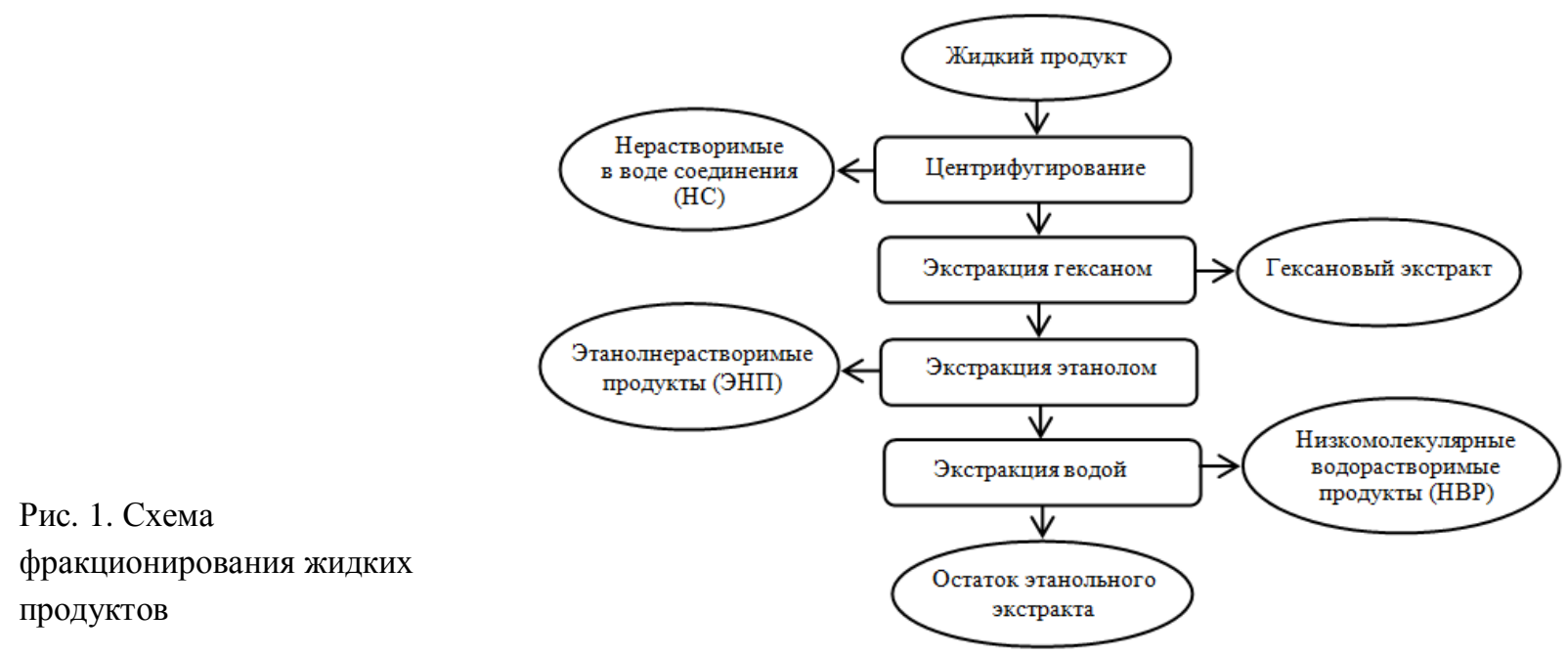


Подготовка образцов для ферментолиза включала сушку при $65-70$ $\mathrm{C}$, измельчение и просеивание с отбором фракции крупностью менее 1 мм. Для гидролиза был использован ферментный комплекс «Целлолюкс-А» с целлюлазной активностью 2000 ед/г (ПО «Сиббиофарм», Бердск). Гидролиз проводили в течение 4 часов при температуре $50{ }^{\circ} \mathrm{C}$, при $\mathrm{pH}$ 4,7-4,8 (ацетатный буфер) и интенсивном перемешивании реакционной среды со скоростью 100 об./мин. Концентрация ферментного препарата в реакционной среде 2,5 мг/мл, отношение массы субстрата к массе раствора составляло $1: 50$. По окончании гидролиза субстрат отделяли от гидролизата фильтрованием. Степень ферментативного гидролиза целлюлозы оценивали по изменению концентрации редуцирующих веществ в гидролизатах, которую определяли методом Дюбуа [18]. Интенсивность поглощения регистрировали на спектрофотометре КФК-3 при 490 нм. Концентрацию углеводов рассчитывали по калибровочному графику, в качестве стандарта для построения калибровочного графика использовали раствор глюкозы с известной концентрацией.

\section{Обсуждение результатов}

Степень конверсии биомассы соломы пшеницы в газообразные и жидкие продукты в динамических условиях процесса субкритического автогидролиза в зависимости от температуры при давлении приведена на рисунке 2. Согласно полученным данным, степень конверсии с повышением температуры увеличивается неравномерно. При $150{ }^{\circ} \mathrm{C}$ она не превышает $23 \%$ на а. с. м. соломы, а при повышении температуры до $200{ }^{\circ} \mathrm{C}$ возрастает более чем в 2 раза. В интервале температур 200-240 ${ }^{\circ} \mathrm{C}$ ее прирост составил не более $5 \%$. При дальнейшем повышении температуры до $270{ }^{\circ} \mathrm{C}$ вновь наблюдается резкий рост степени конверсии до 81,6\%, который затем замедляется и составляет менее $1 \%$ при достижении температуры $290{ }^{\circ} \mathrm{C}$.

На кривой зависимости выхода жидких продуктов от температуры процесса имеются два четко выраженных максимума при температурах 200 и $270{ }^{\circ} \mathrm{C}$ (рис. 2). Выход жидких продуктов при этих температурах составил 48,4 и 47,2\% на а.с.м. соломы соответственно.

Процесс автогидролиза соломы в интервале $150-200{ }^{\circ} \mathrm{C}$ характеризуется низким газообразованием, выход газа не превышает 7\% на а. с. м. соломы. Последующее снижение выхода жидких продуктов в интервале $200-240{ }^{\circ} \mathrm{C}$ сопровождается интенсивным газообразованием, которое при $240{ }^{\circ} \mathrm{C}$ составляет уже $26,5 \%$. Наиболее заметно газообразование при температурах выше $270{ }^{\circ} \mathrm{C}$. При $290{ }^{\circ} \mathrm{C}$ около $50 \%$ биомассы соломы в условиях процесса автогидролиза превращается в газообразные продукты.

На основании сравнительного анализа компонентного состава твердых остатков автогидролиза (табл. 1) можно предположить, что увеличение выхода жидких продуктов в условиях процесса может быть вызвано деструктивными процессами компонентов соломы, прежде всего гидролизом полисахаридов. Процессам гидролитического расщепления могут способствовать как уксусная кислота, образующаяся при дезацетилировании гемицеллюлоз [19], так и вода, проявляющая в субкритических условиях кислотные свойства [20].

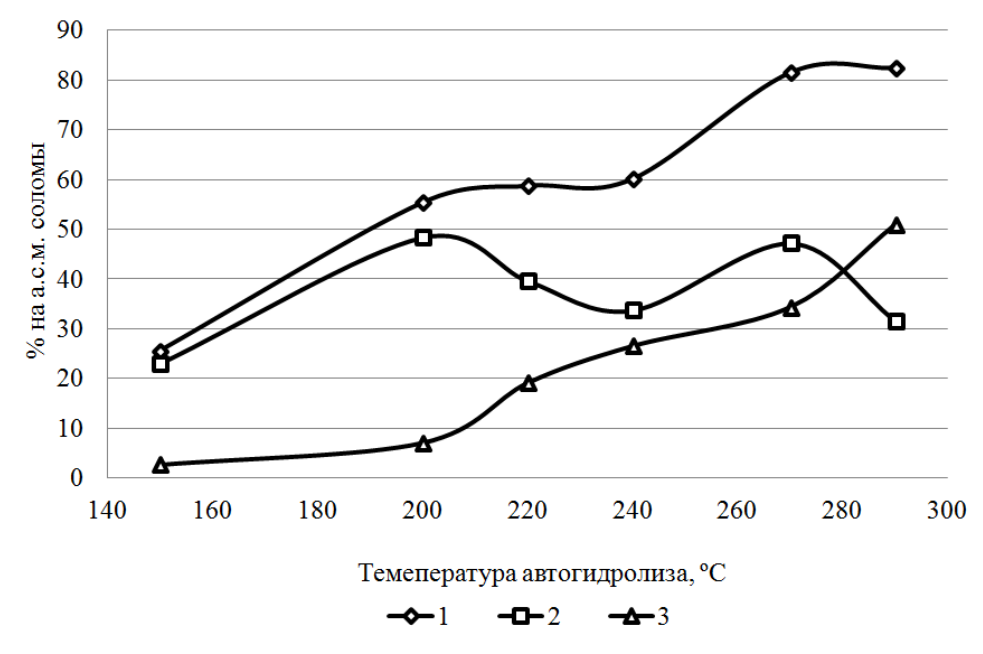

Рис. 2. Зависимость степени конверсии соломы (1), выхода жидких продуктов (2) и газов (3) от температуры субкритического автогидролиза при 30МПа и продолжительности 60 мин 
Таблица 1. Компонентный состав твердых продуктов автогидролиза соломы

\begin{tabular}{c|c|c|c|c|c}
\hline \multirow{2}{*}{ Температура, ${ }^{\circ} \mathrm{C}$} & \multicolumn{2}{|c|}{ Компонентный состав, \% на а.с.м. соломы } & \multirow{2}{*}{$\begin{array}{c}\text { Степень гидролиза } \\
\text { целлюлозы, \% }\end{array}$} & $\begin{array}{c}\text { Степень делиг- } \\
\text { нификации, \% }\end{array}$ \\
\cline { 2 - 5 } & целлюлоза & лигнин & пентозаны & 4,7 & 9,8 \\
150 & 47,7 & 28,8 & 16,5 & 7,7 & 12,7 \\
200 & 52,6 & 31,8 & 12,3 & 24,4 & 33,9 \\
220 & 64,8 & 35,1 & следы & 33,9 & 43,5 \\
240 & 61,2 & 33,4 & 0 & 36,0 & 53,9 \\
270 & 61,5 & 28,3 & 0 & 65,9 & 58,8 \\
290 & 70,6 & 54,5 & 0 & 74,9 & - \\
\hline
\end{tabular}

Наиболее подвержены изменениям в процессе автогидролиза пентозаны. В твердых продуктах, полученных при $175^{\circ} \mathrm{C}$, их содержание в сравнении с содержанием в исходной соломе сократилось на 60,9\%, при $200{ }^{\circ} \mathrm{C}$ пентозаны обнаружены в следовых количествах, а при более высоких температурах они отсутствуют. В этих условиях целлюлоза в меньшей степени подвергается гидролитическому расщеплению. При $200{ }^{\circ} \mathrm{C}$ степень гидролиза целлюлозы не превышает 25\%. Наиболее интенсивно ее гидролиз протекает при температурах выше $240{ }^{\circ} \mathrm{C}$. Как результат, около $75 \%$ целлюлозы исходной соломы при $290{ }^{\circ} \mathrm{C}$ превращаются в жидкие и газообразные продукты. Содержание целлюлозы в твердых продуктах, несмотря на ее гидролиз, в интервале температур 150-270 ${ }^{\circ} \mathrm{C}$ повышается. Снижение ее доли в твердом продукте при $290{ }^{\circ} \mathrm{C}$ может быть вызвано как гидролизом, так и термическими превращениями, о чем свидетельствуют результаты элементного анализа (табл. 2).

Твердые продукты автогидролиза соломы состоят из негидролизованной биомассы, минеральной части и нерастворимых продуктов гидролиза полисахаридов и лигнина. Согласно данным элементного анализа при повышении температуры процесса наблюдается снижение степени насыщенности и степени окисления компонентов твердых продуктов, что может быть следствием как снижения содержания в их составе полисахаридов, так и протекания реакций дегидрирования и дегидратации компонентов соломы.

Согласно изменению степени делигнификации (табл. 1) лигнин в условиях автогидролиза также удаляется, но менее интенсивно в сравнении с полисахаридами, поэтому его доля в твердых продуктах возрастает. Резкое повышение его содержания в твердых продуктах при $270{ }^{\circ} \mathrm{C}$ может быть связано с образованием в результате вторичных превращений псевдолигнина, что согласуется с литературными данными [21]. Его образование снижает точность определения содержания лигнина в твердых продуктах, полученных при более высоких температурах. Кроме того, при определении содержания лигнина в твердом продукте, полученном при $290{ }^{\circ} \mathrm{C}$, выделенный лигнин внешне был похож на коксовый остаток. На основании этого сделано предположение, что твердые остатки, полученные при температурах выше $270{ }^{\circ} \mathrm{C}$, содержат продукты коксования биомассы соломы.

Независимо от температуры процесса динамика выхода жидких продуктов с увеличением продолжительности обработки имеет одинаковый характер (рис. 3). Более $60 \%$ их выхода получено в первые 20 мин автогидролиза. Было замечено, что цвет водного раствора жидких продуктов с увеличением температуры процесса становится более темным.

В составе жидких продуктов в преобладающих количествах присутствуют продукты гидролиза полисахаридов - фракции ЭНП и НВР (рис. 4). При $150{ }^{\circ} \mathrm{C}$ на их долю приходится более 95\%. Повышение температуры автогидролиза сопровождается снижением суммарного содержания этих фракций в жидких продуктах до $68 \%$ при $290{ }^{\circ} \mathrm{C}$ и возрастанием в их составе доли низкомолекулярных водорастворимых соединений.

Таблица 2. Элементный состав твердых продуктов автогидролиза соломы

\begin{tabular}{|c|c|c|c|c|c|c|}
\hline \multirow{2}{*}{$\begin{array}{c}\text { Tемпература, } \\
{ }^{\circ} \mathrm{C}\end{array}$} & \multicolumn{4}{|c|}{ Элементный состав, \% } & \multirow[b]{2}{*}{$(\mathrm{H} / \mathrm{C})_{\mathrm{aT}}$} & \multirow[b]{2}{*}{$(\mathrm{O} / \mathrm{C})_{\mathrm{at}}$} \\
\hline & $\mathrm{C}$ & $\mathrm{H}$ & $\mathrm{O}$ & $\mathrm{N}$ & & \\
\hline 150 & 40,44 & 5,37 & 38,27 & 0,53 & 1,39 & 0,71 \\
\hline 175 & 44,75 & 5,39 & 41,80 & 0,44 & 1,44 & 0,70 \\
\hline 200 & 47,22 & 5,35 & 42,68 & 0,45 & 1,36 & 0,68 \\
\hline 220 & 49,98 & 5,30 & 41,07 & 0,49 & 1,27 & 0,62 \\
\hline 240 & 51,71 & 5,34 & 38,54 & 0,59 & 1,24 & 0,56 \\
\hline 270 & 61,30 & 4,57 & 28,30 & 1,04 & 0,89 & 0,35 \\
\hline 290 & 67,72 & 4,43 & 22,80 & 1,19 & 0,78 & 0,25 \\
\hline
\end{tabular}




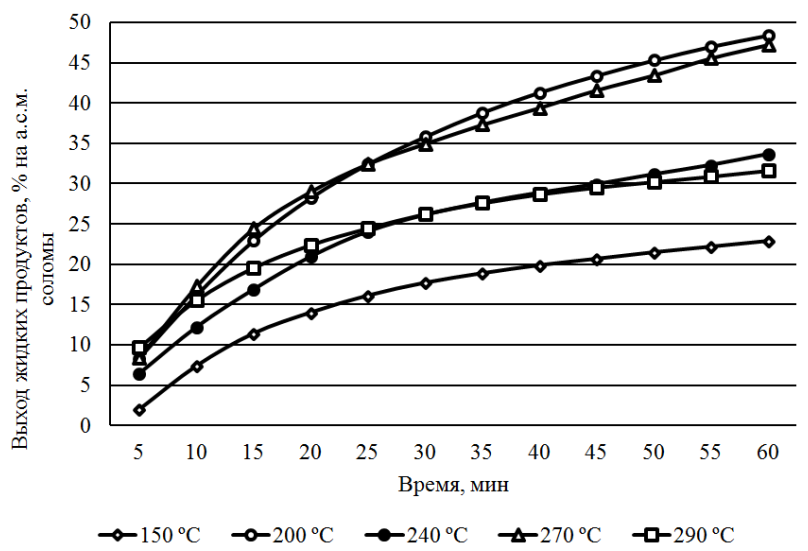

Рис. 3. Динамика выхода жидких продуктов автогидролиза соломы пшеницы (Р = $30 \mathrm{MПа)}$

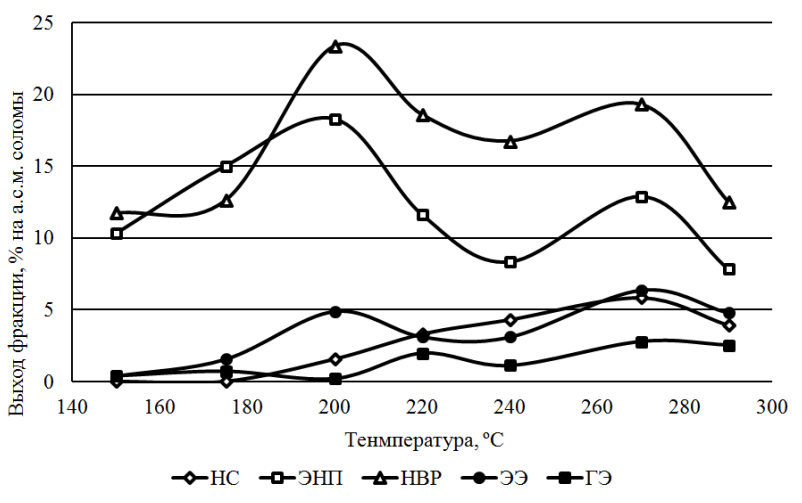

Рис. 4. Фракционный состав жидких продуктов автогидролиза соломы пшеницы

По данным метода ГХ-МС фракции ЭНП и НВР, полученные в интервале температур $150-200{ }^{\circ} \mathrm{C}$, на 65-85\% представлены углеводами (табл. 3). С повышением температуры автогидролиза содержание углеводов во фракциях снижается и при $270{ }^{\circ} \mathrm{C}$ составляет для фракции НВР 20,9\%, а для фракции ЭНП $9,8 \%$. Основными компонентами фракций НВР являются свободные моносахариды, представленные ксилозой, арабинозой, глюкозой, галактозой, фруктозой, маннозой и рамнозой, а фракций ЭНП - олигосахариды. Так, во фракциях НВР и ЭНП, полученных при 200 C, на долю моносахаридов приходится 61,3 и 2,7\%, олигосахаридов - 15,9 и 63,4\% соответственно. В составе исходных фракций, полученных в интервале 150-200 ${ }^{\circ}$, и их гидролизатов доминирующими моносахаридами являются пентозы. При увеличении температуры процесса доля пентоз снижается при одновременном возрастании содержания гексоз.

Наблюдаемые изменения состава моносахаридов в гидролизатах фракций НВР и ЭНП являются следствием процессов, протекающих в определенных температурных интервалах автогидролиза соломы (табл. 3). Так, повышение выхода жидких продуктов в интервале температур $150-200{ }^{\circ} \mathrm{C}$ обусловлено гидролизом гемицеллюлоз соломы. В гидролизатах фракций водорастворимых соединений $\left(200{ }^{\circ} \mathrm{C}\right)$ доминирует ксилоза, а суммарное содержание ксилозы и арабинозы составляет более $65 \%$ на сумму моносахаридов. Снижение их выхода и содержания во фракциях при повышении температуры до $240{ }^{\circ} \mathrm{C}$ вызвано протеканием реакций дегидратации.

Последующее повышение выхода жидких продуктов и в их составе водорастворимых соединений связано с гидролизом целлюлозы соломы. Побуждающим фактором, наряду с повышенной температурой, является субкритическая вода, проявляющая при температурах выше $200{ }^{\circ} \mathrm{C}$ свойства кислотного катализатора [20]. Как следствие, в составе моносахаридов гидролизатов фракций НВР и ЭНП доминирует глюкоза, а на долю пентоз приходится не более $25 \%$ от суммы моносахаридов (табл. 3). Согласно [12] в этих условиях автогидролиза интенсивно протекают процессы превращения глюкозы в 5-оксиметилфурфурол. При анализе методом ГХ-МС состава жидких продуктов автогидролиза соломы пшеницы, полученных в исследуемых условиях, 5-оксиметилфурфурол не обнаружен.

Таблица 3. Состав моносахаридов исходных фракций НВР и ЭНП и их гидролизатов, \% на фракцию

\begin{tabular}{c|c|c|c|c|c|c|c|c}
\hline Фракция & ${\text { Температура, }{ }^{\circ} \mathrm{C}}^{*}$ & Ara & Xyl & Man & Gal & Glc & Fru & Rha \\
\hline \multirow{5}{*}{ HВP } & 150 & 17,40 & 14,50 & 0,43 & 4,42 & 45,50 & 1,90 & 0,90 \\
& 175 & 19,30 & 24,20 & 0,40 & 4,28 & 29,70 & 2,00 & 1,20 \\
& $200^{*}$ & 15,00 & 13,00 & 0,30 & 2,79 & 19,90 & 10,00 & 0,30 \\
& 200 & 14,20 & 35,10 & 0,28 & 3,92 & 20,40 & 2,00 & 1,10 \\
& 220 & 2,04 & 14,20 & 0,18 & 1,70 & 24,80 & 0,78 & 0,11 \\
& 270 & 1,10 & 3,90 & 0,22 & 0,54 & 15,10 & 0,00 & 0,00 \\
\hline \multirow{5}{*}{ ЭНП } & 150 & 15,50 & 25,80 & 0,36 & 5,16 & 27,00 & 3,80 & 1,70 \\
& $200 *$ & 0,80 & 0,70 & 0,00 & 0,11 & 0,90 & 0,20 & 0,00 \\
& 200 & 16,80 & 26,90 & 0,24 & 2,99 & 14,60 & 1,90 & 0,00 \\
& 220 & 0,76 & 8,50 & 0,11 & 1,10 & 22,30 & 0,48 & 0,11 \\
\hline
\end{tabular}

\footnotetext{
* Исходные фракции.
} 
Рис. 5. Зависимость выхода сахаров в составе жидких продуктов от температуры субкритического автогидролиза

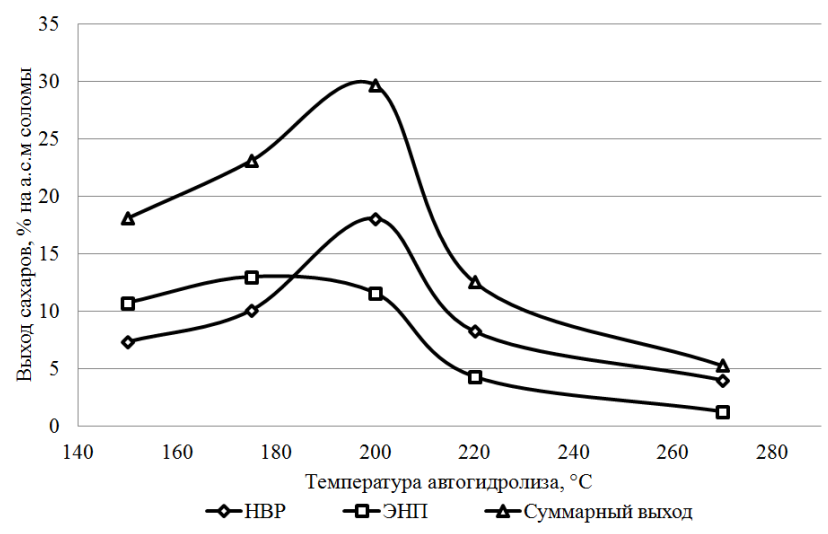

Выход сахаров в составе жидких продуктов автогидролиза в интервале температур $150-270{ }^{\circ} \mathrm{C}$ проходит через максимум при $200{ }^{\circ} \mathrm{C}$ и составляет 29,6\% на а. с. м. соломы (рис. 5). При последующем повышении температуры до $270{ }^{\circ} \mathrm{C}$ их выход снижается до 5,3\%. При температурах процесса до $175^{\circ} \mathrm{C}$ большая часть сахаров выделяется в составе фракции ЭНП, а при повышении температуры - в составе фракции НВР.

По данным ГХ-МС в гидролизатах фракций наряду с моносахаридами присутствуют одно-, двух- и трехосновные жирные кислоты, гидроксикислоты, аминокислоты, многоатомные спирты и фенольные соединения. Присутствием разнообразных кислот можно объяснить низкие значения рН-среды жидких продуктов автогидролиза соломы, что наиболее заметно при проведении процесса при повышенных температурах. При $200{ }^{\circ} \mathrm{C}$ значение рН-среды фракций жидких продуктов, выделенных из соломы в течение первых 10 мин, снизилось с 6,5 до 4,1 и затем в течение последующих 50 мин - до 3,9. При $270{ }^{\circ} \mathrm{C}$ рН-среды водного раствора продуктов автогидролиза был ниже и составил 3,6. Аналогичная зависимость рН-среды получаемых жидких продуктов от продолжительности и температуры обработки была выявлена при субкритическом автогидролизе рисовых отрубей [11].

Формируемая в процессе автогидролиза кислая среда способствует расщеплению лигноцеллюлозного комплекса соломы по эфирным связям. Образующиеся низкомолекулярные продукты гидролиза полисахаридов и лигнина удаляются в условиях процесса в составе жидких продуктов. При этом содержание целлюлозы в твердых продуктах в исследуемом интервале температур процесса повышается. Несмотря на практически полное удаление гемицеллюлоз и частичное лигнина оставшаяся часть целлюлозы в твердых остатках соломы, полученных при $200{ }^{\circ} \mathrm{C}$, проявляет низкую реакционную способность к ферментативному гидролизу. Степень ферментолиза целлюлозы твердого остатка составила 20,1\%, в то время как для целлюлозы исходной соломы этот показатель равен 25,8. Тем не менее с помощью ферментативного гидролиза из твердого остатка автогидролиза дополнительно было получено сахаров в количестве 5,3\% на а.с.м. соломы.

\section{Выводы}

1. В динамических условиях субкритического автогидролиза более $80 \%$ биомассы соломы пшеницы было переведено в газообразные и жидкие продукты без использования органических растворителей и кислотного катализатора. Соотношение выходов указанных продуктов определяется температурой процесса.

2. В интервале $150-200{ }^{\circ} \mathrm{C}$ формирование жидких продуктов, на долю которых приходится более $90 \%$ от общего выхода, осуществляется в основном за счет гидролиза пентозанов и частично - целлюлозы.

3. Повышение температуры в интервале 200-290 ㄷ сопровождается понижением рН-среды, гидролизом целлюлозы, интенсивным газообразованием и конденсацией продуктов гидролиза лигнина и полисахаридов с образованием псевдолигнина.

4. Суммарный выход продуктов гидролиза полисахаридов проходит через максимум при $200{ }^{\circ} \mathrm{C}$ с последующим снижением с 29,6 до 5,3\% на а.с.м. соломы при $270{ }^{\circ} \mathrm{C}$. Выявлено, что не гидролизованная при $200{ }^{\circ} \mathrm{C}$ часть целлюлозы, в сравнение с исходной, характеризуется меньшей реакционной способностью при ферментолизе. 


\section{Список литературы}

1 Kim J.S., Lee Y.Y., Torget R.W. Cellulose hydrolysis under extremely low sulfuric acid and high-temperature conditions // Biochem. Biotechnol. 2001. Vol. 91-93(1-9). Pp. 331-340.

2 Ortega N., Busto M.D., Perez-Mateos M. Kinetics of cellulose saccharification by Trichoderma reesei cellulases // Int. Biodeterior Biodegrad. 2001. Vol. 47(1). Pp. 7-14.

3 Wiboonsirikul J., Kimura Y., Kadota M., Morita H., Tsuno T., Adachi S. Properties of extracts from defatted rice bran by its subcritical water treatmen // Food Chem. 2007. Vol. 55 (21). Pp. 8759-8765.

4 Alvira, P., Tomás-Pejó, E., Ballesteros, M., Negro, M.J. Pretreatment technologies for an efficient bioethanol production process based on enzymatic hydrolysis: A review // Bioresource Technology. 2010. Vol. 101 (13). Pp. 48514861

5 Talebnia F., Karakashev D., Angelidaki I. Production of bioethanol from wheat straw: An overview on pretreatment,hydrolysis and fermentation // Bioresource Technology. 2010. Vol. 101 (13). Pp. 4744-4753

6 Pourali O., Asghari F.S., Yoshida H. Subcritical water treatment of rice bran to produce valuable materials. Review // Food Chemistry. 2009. Vol. 115 (1). Pp. 1-7

7 Luque de Castro M.D., Jimenez-Carmona M.M., Fernandez-Perez V. Towards more rational technique for the isolation of valuable essential oils from plant // Trends Anal. Chem. 1999. Vol. 18 (11). Pp. 708-716.

8 Bicker M., Endres S., Ott L.,Vogel H. Catalytical conversion of carbohydrates in subcritical water: A new chemical process for lactic acid production // Journal of Molecular Catalysis A: Chemical. 2005. Vol. 239. Pp. 151-157.

9 Kruse A., Gawlik A. Biomass conversion in water at $330-410{ }^{\circ} \mathrm{C}$ and $30-40 \mathrm{MPa}$. Identification of key compounds for indicating different chemical reaction pathways // Industrial and Engineering Chemistry Research. 2003. Vol. 42 (2). Pp. 267-279.

10 Asghari F.S., Yoshida H. Kinetics of the decomposition of fructose catalyzed by hydrochloric acid in subcritical water: Formation of 5- hydroxymethylfurfural, levulinic, and formic acids // Industrial and Engineering Chemistry Research. 2007. Vol. 46 (23). Pp. 7703-7710.

11 Pourali O., Asghari F.S., Yoshida H. Production of phenolic compounds from rice bran biomass under subcritical water conditions // Chemical Engineering Journal. 2010. Vol. 160. Pp. 259-266.

12 Ingram T., Rogalinski T., Antranikian G., Bockemühl V., Brunner G. Semi-continuous liquid hot water pretreatment of rye straw // The Journal of Supercritical Fluids. 2009. Vol. 48 (3). Pp. 238-246.

13 Pérez J.A., Ballesteros I., Ballesteros M., Sáez F., Negro M.J., Manzanares P. Optimizing liquid hot water pretreatment conditions to enhance sugar recovery from wheat straw for fuel-ethanol production // Fuel. 2008. Vol. 87 (1718). Pp. 3640-3647.

14 Евстафьев С.Н., Фомина Е.С., Привалова Е.А. Этанолиз пшеничной соломы в условиях до- и сверхкритической экстракции // Химия растительного сырья. 2011. №4. С. 15-18.

15 Оболенская А.В., Ельницкая 3.П., Леонович А.А. Лабораторные работы по химии древесины и целлюлозы : учебное пособие для вузов. М., 1991. 320 с.

16 Иванова Н.В., Оводова Р.Г., Бабкин В.А. Общая характеристика полисахаридов коры лиственницы // Химия растительного сырья. 2006. №1. С. 15-20.

17 Оводов Ю.С. Газожидкостная хроматография углеводов. Обзор. Владивосток, 1970. 70 с.

18 DuBois M., Gilles K.A., Hamilton J.K., Rebers P.A., Smith F. Colorimetric method for determination of sugars and related substances // Analyt. Chem. 1956. Vol. 28 (3). Pp. 350-356.

19 Старцев О.В., Салин Б.Н., Скурыдин Ю.Г. Баротермический гидролиз древесины в присутствии минеральных кислот. Доклады академии наук // Химическая технология. 2000. Т. 370. №5. С. 638-641.

20 Hata S., Wiboonsirikul J., Maeda A., Kimura Y., Adachi S. Extraction of defatted rice bran by subcritical water treatment // Biochem. Eng. J. 2008. Vol. 40. Pp. 44-53.

21 Калейне Д.А., Веверис А.Г., Полманис А.Г., Эриньш П.П. и др. Высокотемпературный автогидролиз древесины. Автогидролиз березовой древесины // Химия древесины. 1990. №3. С. 101-107.

Поступило в редакииюю 8 сентября 2014 г. 
Chechikova E.V., Evstafev S.N. TRANSFORMATIONS OF WHEAT STRAW POLYSACCHARIDES IN DYNAMIC CONDITIONS OF SUBCRITICAL AUTOHYDROLYSIS

Irkutsk State Technical University, Lermontova st., 83, Irkutsk, 664074 (Russia), e-mail: artelzin@mail.ru

Behavior of wheat straw polysaccharides in dynamic conditions of subcritical autohydrolysis was examined with a pressure of $30 \mathrm{MPa}$ in the temperature range of $150-290{ }^{\circ} \mathrm{C}$. The dependence of the yield of gaseous, liquid and solid products from the process temperature is studied. The formation of liquid products is mainly performed due to the hydrolysis of pentosans and partially of cellulose in the range of $150-200{ }^{\circ} \mathrm{C}$. The main components of the liquid products are oligosaccharide and monosaccharide. The monosaccharide is more than $65 \%$ of xylose and arabinose. The temperature rise in the range of $200-290{ }^{\circ} \mathrm{C}$ is accompanied by a decrease in medium $\mathrm{pH}$, the hydrolysis of cellulose and intensive gasification. The monosaccharide of liquid products isolated at $270{ }^{\circ} \mathrm{C}$ is mainly composed of glucose and no more than $25 \%$ of pentose of the amount of monosaccharide. With the temperature rise of the process the maximal yield of sugars is at $200{ }^{\circ} \mathrm{C}$ and then it decreased from 29,6 to $5,3 \%$ for bone-dry solid matter of the straw at $270{ }^{\circ} \mathrm{C}$. The decrease of the reactivity of cellulose straw treated at $200{ }^{\circ} \mathrm{C}$ to enzymatic hydrolysis is established.

Keywords: wheat straw, subcritical autohydrolysis, cellulose, pentosans, sugars.

\section{References}

1. Kim J.S., Lee Y.Y., Torget R.W. Biochem. Biotechnol., 2001, vol. 91-93(1-9), pp. 331-340.

2. Ortega N., Busto M.D., Perez-Mateos M. Int. Biodeterior Biodegrad, 2001, vol. 47(1), pp. 7-14.

3. Wiboonsirikul J., Kimura Y., Kadota M., Morita H., Tsuno T., Adachi S. Food Chem., 2007, vol. 55 (21), pp. 8759-8765.

4. Alvira, P., Tomás-Pejó, E., Ballesteros, M., Negro, M.J. Bioresource Technology, 2010, vol. 101 (13), pp. 4851-4861

5. Talebnia F., Karakashev D., Angelidaki I. Bioresource Technology, 2010, vol. 101 (13), pp. 4744-4753

6. Pourali O., Asghari F.S., Yoshida H. Food Chemistry, 2009, vol. 115 (1), pp. 1-7

7. Luque de Castro M.D., Jimenez-Carmona M.M., Fernandez-Perez V. Trends Anal. Chem., 1999, vol. 18 (11), pp. 708-716.

8. Bicker M., Endres S., Ott L.,Vogel H. Journal of Molecular Catalysis A: Chemical, 2005, vol. 239, pp. 151-157.

9. Kruse A., Gawlik A. Industrial and Engineering Chemistry Research, 2003, vol. 42 (2), pp. 267-279.

10. Asghari F.S., Yoshida H. Industrial and Engineering Chemistry Research, 2007, vol. 46 (23), pp. 7703-7710.

11. Pourali O., Asghari F.S., Yoshida H. Chemical Engineering Journal, 2010, vol. 160, pp. 259-266.

12. Ingram T., Rogalinski T., Antranikian G., Bockemühl V., Brunner G. The Journal of Supercritical Fluids, 2009, vol. 48 (3), pp. 238-246.

13. Pérez J.A., Ballesteros I., Ballesteros M., Sáez F., Negro M.J., Manzanares P. Fuel, 2008, vol. 87 (17-18), pp. 3640-3647.

14. Evstaf'ev S.N., Fomina E.S., Privalova E.A. Khimiia rastitel'nogo syr'ia, 2011, no. 4, pp. 15-18. (in Russ.).

15. Obolenskaia A.V., El'nitskaia Z.P., Leonovich A.A. Laboratornye raboty po khimii drevesiny i tselliulozy. [Laboratory work on the chemistry of wood and cellulose]. Moscow, 1991, 320 p. (in Russ.).

16. Ivanova N.V., Ovodova R.G., Babkin V.A. Khimiia rastitel'nogo syr'ia, 2006, no. 1, pp. 15-20. (in Russ.).

17. Ovodov Iu.S. Gazozhidkostnaia khromatografiia uglevodov. Obzor. [Gas-liquid chromatography of carbohydrates. Overview]. Vladivostok. 1970, 70 p. (in Russ.).

18. DuBois M., Gilles K.A., Hamilton J.K., Rebers P.A., Smith F. Analyt. Chem., 1956, vol. 28 (3), pp. 350-356.

19. Startsev O.V., Salin B.N., Skurydin Iu.G. Khimicheskaia tekhnologiia, 2000, vol. 370, no. 5, pp. 638-641. (in Russ.).

20. Hata S., Wiboonsirikul J., Maeda A., Kimura Y., Adachi S. Biochem. Eng. J., 2008, vol. 40, pp. 44-53.

21. Kaleine D.A., Veveris A.G., Polmanis A.G., Erin'sh P.P. et all. Khimiia drevesiny, 1990, no. 3, pp. 101-107. (in Russ.).

Received September 8, 2014

Revised December 25, 2014

\footnotetext{
* Corresponding author.
} 
